\title{
A Review of Issues Pertaining to Transgenic Turfgrasses
}

\author{
Paul G. Johnson ${ }^{1}$ \\ Department of Plants, Soils, and Biometeorology, Utah State University, Logan, UT 84322-4820 \\ Terrance P. Riordan ${ }^{2}$ \\ Department of Horticulture, University of Nebraska, Lincoln, NE 68583-0724
}

Recombinant DNA technology is a rapidly growing field in plant and animal breeding. This technology involves the transfer of pieces of DNA, or genes, regardless of the organisms involved or how they are related. Transformation procedures in plants were first developed for important crop and model plant systems. Although turfgrass management and production is one of the fastest growing areas of agriculture, genetic transformation of turfgrasses lags behind that of many other important crop plants. Turfgrasses are becoming more important primarily because of their association with the ever-increasing urban population. The size of the turfgrass seed market is second only to that of hybrid seed corn (Lee, 1996). However, much less is known about the genetics and physiology of turfgrasses. Many are polyploid, perennial, and/or outcrossing. These characteristics make them more difficult to study than many other crop plants. Use of transgenic technology in turfgrasses will likely follow as interest and corporate motivations allow.

Application of transgenic technology is virtually limitless. The past few years have seen a rapid increase in releases of transgenic plants. Between 1987 and 1997, 3330 permits and notifications were filed with the U.S. Dept. of Agriculture (USDA-APHIS, 1998) for release of genetically engineered organisms in the United States. Twenty-nine percent involved herbicide tolerance and $24 \%$ insect resistance. Compared with the major crop species, genetically engineered turfgrasses are uncommon. By Dec. 1998, 31 permits and notifications had been filed on creeping bentgrass (Agrostis stolonifera L.) and two notifications on Kentucky bluegrass (Poa pratensis L.) (USDA-APHIS, 1998). But as additional genes are identified and cloned, a myriad of traits will probably be introduced into the turfgrasses.

The first applications of transformation in turfgrasses were the incorporation of glufosinate [ $N, N$-bis (phosphomethyl)glycine] resistance into creeping bentgrass (Lee et al., 1996; Liu et al., 1998), allowing application of a very effective nonselective herbicide to control unwanted weeds or other turfgrasses. In the future, recombinant DNA technology may

Received for publication 24 Sept. 1998. Accepted for publication 24 Dec. 1998. Utah Agricultural Experiment Station Publication No. 7079. The cost of publishing this paper was defrayed in part by the payment of page charges. Under postal regulations, this paper therefore must be hereby marked advertisement solely to indicate this fact.

${ }^{1}$ AssistantProfessor.E-mail:pjohnson@mendel.usu.edu ${ }^{2}$ Professor. be used to introduce other traits, such as insect resistance, disease resistance, and improved environmental stress tolerance.

Transformation technology may offer many economic and agronomic benefits that are difficult or impossible to achieve through traditional breeding techniques (Dale, 1993). Essential steps of recombinant DNA technology include identification of the gene of interest, its isolation (cloning), study of the gene's function and regulation, and introduction of the gene and expression factors into cells (Marois et al., 1991). Finally, the traits must be evaluated in an agriculturally desirable genotype.

Plant breeders have been transferring genes to crop species from other species, and even from other genera, for many years through hybridization. Therefore, transformation technologies are often considered not inherently different from traditional methods of plant breeding. However, these methods are hotly debated in scientific and media circles. Mutation breeding, the use of irradiation to produce novel-type plants, has also been used for many years. No problems have been recorded after the release of $>1550$ officially registered varieties or cultivars using these techniques (Rodgers and Parkes, 1995). Transformed plants might be expected to have a similar safety record. However, some argue that plant transformation is different because genes are transferred without regard to life form (Rodgers and Parkes, 1995). Thus, potential risks should be considered before and during widespread release of genetically engineered turfgrasses.

Many laboratories around the world are investigating the potential environmental impact of transgenic plants. Very little information is available that addresses the specific issues of transformed turfgrasses and their management. Plant regeneration protocols have recently been developed for some species of turfgrasses, including Agrostis, Festuca, and Lolium, and transfer of genes controlling resistance to disease, stress, and herbicides has been achieved (Lee, 1996; Lee et al., 1996; Spangenberg et al., 1998; Warkentin et al., 1998). Additional species are being transformed. We will not review in depth the potential hazards and general issues of transformed plants because this has been adequately reviewed by others (Dale and Irwin, 1995; Dyer et al., 1993; Rodgers and Parkes, 1995). Rather, we will analyze the benefits, potential problems, public perceptions, and the research that is needed regarding transformed turfgrasses. This information can then be used by other researchers to fill needed information gaps and to develop genetically engineered turfgrasses.

\section{POTENTIAL BENEFITS}

Agricultural biotechnology has occasionally been described as having the potential of producing the next "green revolution." The truth of this statement remains to be seen. The potential for crop plants has been reviewed by a number of authors (Dyer et al., 1993; Marois et al., 1991), but much of the discussion regarding the economic aspects of herbicide resistance in crop plants is not applicable to turf ecosystems because of the differences between the cropping systems and user expectations. Herbicide-resistant turfgrasses may lead to increased efficiency and lower costs of production and management because weed control may be more effective and conducted with relatively inexpensive products. Use of herbicide-resistant cultivars may be the only effective means of selectively controlling some weeds in some turfgrass systems. In turfgrass management, quality of the product is more important than quantity of product. This leads to very low weed thresholds and pest tolerances. In the case of weed control, these expectations might be most effectively obtained with an herbicide resistance package (a combination of an herbicide-resistant cultivar and the associated herbicide). An excellent example of such a situation is the golf course. The recent boom in the popularity of golf has created great demands for higher quality and increased tolerance traffic. Golf course managers are eager to use the herbicide-resistant grasses, and companies are beginning to respond to this desire and potential market.

The use of herbicide-resistant turfgrasses may also be beneficial to the environment. The two herbicides most commonly used in these programs are glyphosate $[N$ (phosphonomethyl)glycine] and glufosinate. Both have lower mammalian toxicity and lower rates of application than many other herbicides. Only one application may be needed to control a problem weed, while repeated applications of other herbicides are often needed. Nonselective herbicides also fit into an integrated pest management program. Weeds would only be sprayed when they appear, rather than using blanket applications in preventive programs.

Herbicide-resistant turfgrasses will provide the opportunity for wide-spectrum weed control, resulting in improved turfgrass quality and improved sports turf because of increased uniformity. Weed management may be simplified, resulting in reduced chemical use. On the other hand, herbicide use might increase because of the simplicity of the weed control method. Rather than fixing underlying 
cultural problems (i.e., compaction, nutrient deficiencies), some turfgrass managers may use chemical weed control. As scientists, we may consider glyphosate and glufosinate to be "safe" chemicals, but the general public may not concur.

\section{POTENTIAL RISKS}

With any new technology come some risks or potential new problems. The potential effects of transgenic turfgrasses on the environment have been actively debated. These risks can be put into three broad categories: 1) the introduced gene causes the turfgrass to become a pest to other crops in agricultural or turf situations; 2) the introduced gene is transferred to other species by cross-pollination, especially to weedy species, thereby causing additional weed problems; 3 ) resistant weeds develop by natural selection following repeated usage of the same herbicide. Other concerns have also been raised about transformed plants, including the production and dissemination of transgene products in pollen and seed, toxicity of the transgene products, and stability of gene expression. These are of lesser concern in turfgrass; for more information on these topics refer to Rodgers and Parkes (1995).

\section{Transformed plant becomes a weed}

Most turfgrass species are not considered weeds in agricultural systems. An exception (in some areas of the United States) is bermudagrass (Cynodon dactylon L.), which will be discussed later in this review. Turfgrasses are not weeds in cropland because they are relatively slow growing, small in stature, and quickly shaded or out-competed by most crop plants. Tillage practices and herbicides also prevent turfgrasses from competing in the field crop environment. Currently, most species used for turfgrass applications exist near fields, yet do not present a weed problem. Kentucky bluegrass is naturalized to the northern United States and becomes established in roadsides and fence rows. However, in the immediately adjacent cultivated fields, it is not a significant weed problem. The addition of herbicide resistance will probably not change the competitiveness of the turfgrass plant and thus will not cause additional problems. Weediness might be considered a multigenic trait. Therefore, the introduction of one or a few genes into turfgrass may not result in a problem weed (Arnoldo et al., 1992; Crawley et al., 1993; DeGreef, 1989; Dyer et al., 1993; Fredshaven and Poulsen, 1996) unless accompanied by major changes, such as increased growth rate and stature, reproductive allocation, and life cycle characteristics (Bazzaz, 1986).

Andow (1994) reports that in order for a transformed plant to become more competitive, the introduced gene must lower the plant's minimum resource requirement. Herbicide resistance is relatively benign in that the only competitive advantage it confers is when an herbicide is used. If the transformed plant should escape, it will be no more competitive than nontransformed plants. In fact, the resistance gene may impart a competitive disadvantage in the absence of the herbicide (Bergelson et al., 1996; Dyer et al., 1993). In this situation, after a number of generations without herbicide selection, the resistance gene may become very rare or be eliminated. If it does not reduce the plant's competitiveness, the gene will remain at a low frequency in the populations. Andow's (1994) model fits perennial grasses well, because it factors in biomass accumulation, but not seed dispersal and reproduction.

The insertion of other traits may have more effect on competitiveness. Introduced traits for increased cold tolerance, drought tolerance, tolerance to low $\mathrm{pH}$, and other stresses may influence the plant distribution by making it more competitive (Fredshaven and Poulsen, 1996; Holmberg and Bulow, 1998). Therefore, each trait will need to be considered individually for its effect.

\section{Gene transfer to weedy relatives}

Although herbicide-resistant turfgrasses may not become weeds in themselves, closely related species may become problems. Crosspollination can occur among species and occasionally among genera, enabling gene transfer to a wide range of plants. Gene transfer has been repeatedly demonstrated between a crop plant and a related species growing in close proximity (Hancock et al., 1996; Rodgers and Parkes, 1995). Because cross-compatibility among turfgrass species has not been studied extensively, we will discuss examples from a few crop plants to describe the potential problem of transferring an herbicide resistance gene into a weedy population.

Weedy or wild-type sunflowers (Helianthus annuus L.) frequently grow within the fields of cultivated sunflowers. This offers an ideal situation for gene transfer. Arias and Riesberg (1994) traced one allele present in the cultivated plant but not in the weedy populations. Twenty-seven percent gene flow was observed within $3 \mathrm{~m}$ of the cultivar, and measurable gene flow was observed up to $1000 \mathrm{~m}$ from the source.

However, this much gene flow is not the rule. Luby and McNicol (1995) followed a trait in raspberries (Rubus idaeus L.) that was introduced via traditional breeding 30 years ago. They observed little gene flow overall. The trait was observed at a low frequency $(0.004)$ in wild populations of raspberry near the fields, but was not found in more remote areas. Luby and McNicol concluded that genes controlling traits of neutral selective value will remain localized. Strong selection pressures have been applied to weed populations since the advent of selective herbicides with no reports of gene transfer between crop and weed (Dyer et al., 1993). In turfgrasses, the only real potential for significant movement by hybridization is in seed fields. Most turf areas are mowed often, preventing the dispersal of pollen and completion of seed development.

\section{Development of resistant weed populations}

A short-term problem that may occur with herbicide-resistant turfgrasses is the tendency for turf managers to become more dependent on the herbicide. If the same or similar herbicides are used repeatedly in the same location, resistance may develop in the weed populations. Although weeds have the potential to acquire resistance through cross-hybridization, some weed species are more likely to develop resistance independently through selection pressure. There is little research documenting the development of resistance in target weed populations of turfgrasses, but we can look at the development of resistance weed populations in crop plants as examples.

Overall, there has been a steady increase since the 1960s in resistant weed species and in number of herbicide classes to which they are resistant (Heap, 1997; Moss and Rubin 1993; Putwain, 1990). Recently, resistance to herbicides that inhibit acetolactate synthase (ALS) have appeared within as few as 4 years of application (Saari et al., 1994). Fortunately, few cases have developed where the resistant weeds could not be controlled by using other herbicides or weed control measures. However, as weeds develop resistance to more than one herbicide, more problems may arise. In Australia, a population of Lolium rigidum Gaud. is resistant to up to 10 different herbicide classes (Rodgers and Parkes, 1995). Triazine resistance is widespread in crop plants (Saari et al., 1994). Herbicide tolerance in plants may occur in a number of ways: overproduction of herbicide target site (enzyme); reduced herbicide uptake; degradation of the herbicide; or detoxification and alteration in the site of herbicide action (Dyer et al., 1993). These are ways that scientists can manipulate plants, but are also ways that weeds can evolve in response to strong selection pressures.

Some weeds in turf have many characteristics of resistance development. If herbicideresistant creeping bentgrass varieties are developed, a major weed that will be targeted is Poa annua L. But this is an extremely variable species (Johnson, 1995; Johnson et al., 1993), has a very large soil seed bank (Lush, 1988), a fast generation time (Johnson, 1995; Johnson et al., 1993), and gene flow between populations (Wu et al., 1987). In a crop such as turfgrass, where appearance is of utmost importance, the tolerance for weeds is often very low, making the selection intensity for resistance very high. High selection intensity dictates that only those plants with the highest level of a characteristic will be selected (in this case, unintentionally). All of these characteristics create an ideal situation for developing resistance. At least some Poa annua populations are triazine-resistant (Darmency and Gasquez, 1983) and/or sethoxydim [2-(1(ethoxyimino)-5-(2-(ethylthio)propyl)-3-hydroxy-2-cyclohexen-1-one] (D.B. White, personal communication). Ecological research on population changes due to management, particularly herbicide management, is needed to determine the extent of this potential prob- 
lem. The potential for development of resistance to glyphosate has been determined to be "low-risk" (LeBaron and McFarland, 1990). However, important differences between crop management and turf management systems mean that the potential for resistance must be readdressed. Probably the most important factor affecting resistance development in turfgrass communities is the lack of rotation and cultivation as a means of weed control. Because crops are not rotated in turfgrass areas, the same herbicide and cultural control methods are used on the same weed populations year after year.

As mentioned above, glyphosate is considered relatively safe from the standpoint of the development of resistant weed populations, but reports from Australia indicate significant resistance has developed in Lolium rigidum Gaud. (Powles et al., 1998; Pratley et al., 1996). Resistance has been and will continue to be slow to develop because of the difficulties in obtaining glyphosate-resistant enzymes with normal activity (Dyer et al., 1993). The development of resistance to glufosinate has not been reported in the literature, perhaps because of its more recent development as an herbicide.

Because crop rotation is out of the question in turf areas, rotation of herbicides would be useful in preventing or delaying resistance. Multiple resistance would prevent or slow the development of herbicide resistance in the weed populations; however, the inclusion of more than one resistance gene may limit renovation and management tools. At this time, the number of nonselective herbicides is limited, with glyphosate and glufosinate as the only ones widely used on turfgrass and landscape sites. Once herbicide resistance genes are more widely used and economic benefits are realized for chemical companies, a strong economic incentive will exist for the development of new herbicides and resistance mechanisms (Saari et al., 1994). If additional nonselective herbicides are developed, two or three herbicide resistance genes could be inserted into a turfgrass species, allowing rotation of herbicides. Sensitivity to other herbicides would still leave an outlet for nonselective control.

Unfortunately, little literature exists on the potential of hybridization and gene transfer to weedy relatives of turfgrasses, possibly because the number of related species is small and of historically limited economic importance. Estimating risk is speculative without a long-term study of crop plantings, sympatric wild or weedy relatives, the reproductive systems, and seed and pollen dispersal (Luby and McNicol, 1995).

\section{New technology}

The concern over the spread of transgenes in many crops has led to much research in developing transformation systems, gene constructs, promoter development, etc., to decrease the chance of gene transfer via sexual reproduction, seed, or pollen. Insertion of the resistance genes into the choroplast genome prevents transfer of the genes by pollen (Daniell et al., 1998). The seed of the transgenic plant can also be killed if a particular treatment is not given. Such plant protection methods have been nicknamed "terminator" technology (Service, 1998). Chemically induced promoters have also been used (Gatz and Lenk, 1998). Further advances in promoter technology will enhance control over transgene expression (Gallie, 1998). If past technological advances in these areas are a guide, nearly any possible scenario, no matter how esoteric, may be possible in the future.

\section{SPECIFIC CASES FOR TURFGRASS SPECIES}

Several factors must be considered in each turfgrass species for potential gene transfer: 1) the proximity and number of potentially weedy relatives that can act as a maternal parent; 2) sexual compatibility of these relatives; 3 ) the fertility of offspring of such crosses; 4) selection pressures that act on the hybrid progeny; 5) fitness of hybrids under agricultural and turfgrass situations. These issues are considered for several important turfgrass species in the following section.

\section{Kentucky bluegrass}

The genus Poa includes $\approx 70$ species, some of which are found in all 48 contiguous United States (Hitchcock, 1950). Their abundance and close proximity indicate high probability of sexual compatibility between species and the potential for interspecific hybridization. However, the occurrence of hybrids is infrequent among the species used as turfgrasses or those used as turfs probably because of a high percentage of apomictic progeny. Poa pratensis has been hybridized in laboratory settings with other species; however, the likelihood of these crosses occurring in nature is small. Still, the possibility exists, most notably among Poa compressa L., P. trivialis L., and $P$. annua, all of which may be found in or near turfgrass seed fields. In addition, colonization of a new plant into an established plant community requires numerous introductions, unless the plant is remarkably fit (Bazazz, 1986). Both predicting the chance of gene spread into weedy species and detecting when it occurs are difficult. Careful evaluation of large-scale deployment may be the best way to study gene transfer in Poa.

If transmission to other Poa species occurs, it would most likely happen in seedgrowing regions in the northwestern United States and northern Minnesota. In these locations, herbicides are applied repeatedly to the same area and plants are allowed to flower each year. This allows hybridization between turf species and weeds, as well as repeated selection pressure for herbicide resistance. Gene transfer will probably not occur in turf areas, since the grasses are mowed and usually not allowed to flower and set seed.

Should resistance develop in closely related Poa species, the situation is no different from that existing today, because a selective herbicide is not available to remove these weedy Poa species from Kentucky bluegrass seed fields. However, a tool for renovation to remove all vegetation would be lost. Of greater importance is the movement of the herbicideresistant weed seed from these fields to turf areas around the world. Supplies of grass seed may be more vulnerable than supplies of other crop seeds because similar varieties are grown over large portions of the world. Quality control measures, such as shorter field life, better seed field isolation, tighter scouting, and seed testing, might help reduce transfer of herbicide resistance genes into these weedy populations, and the movement of that seed into seed supplies. If herbicide-resistant Poa trivialis, $P$. annua, and $P$. compressa do develop, they will likely not be problems in agricultural areas for reasons discussed previously. Additional changes in the plant, other than herbicide resistance, would have to develop for them to be competitive in field situations.

\section{Creeping bentgrass, tall fescue, fine fescues, and ryegrass}

The genera Agrostis, Festuca, and Lolium each include a relatively large number of species $(>25)$, some of which are found throughout the 48 contiguous states (Hitchcock, 1950). There are numerous reports and examples of intergeneric and interspecific hybridization within and between Festuca and Lolium. Therefore, the potential exists for transformed gene transfer among and within these genera. There are also examples of interspecific hybridization in Agrostis; however, most of the crosses with creeping bentgrass will be sterile because of differing ploidy levels between the species (Jones, 1956a, 1956b, 1956c). Information on the amount of outcrossing among Agrostis species does not exist for turfgrass seed production and managed turfgrass areas.

These genera are not weeds in most crop systems and introduced herbicide resistance probably will not alter their competitiveness, as previously described. Bentgrass and tall fescue are more commonly weeds in some turfgrass situations because they differ in color and growth habit from Kentucky bluegrass, ryegrass, etc. Introducing herbicide resistance to tall fescue and creeping bentgrass would not change their competitiveness. Resistance would reduce chemical tools available for renovating turfs contaminated with those grasses. As long as other nonselective herbicides are available, renovation will still be possible.

Of greater concern is the use of herbicideresistant creeping bentgrass on golf greens and subsequent control of annual bluegrass ( $\mathrm{Poa}$ annua). The potential for herbicide resistance in Poa annua has been described and is very real. Larger-scale release and careful scrutiny will be needed for evaluation.

\section{St. Augustinegrass and buffalograss}

Outcrossing possibilities in St. Augustinegrass [Stenotaphrum secundatum (Walt.) Kuntze] and buffalograss [Buchloe dactyloides (Nutt.) Engelm.] are much more limited than 
in the other grasses discussed. Both are the only species of their genera in the United States, and no literature could be located to indicate intergeneric hybridization. The chance of gene transfer is essentially zero. A more important concern in these species is the development of resistance in weedy populations of bermudagrass, as it will be a chief target for weed control efforts in buffalograss and St. Augustinegrass turfs. If herbicide resistance or another characteristic develops in the bermudagrass populations, it could affect agricultural systems in the southern United States.

\section{Bermudagrass}

Bermudagrass is considered a noxious weed in some parts of the United States in both turf and nonturf areas. Because of potential problems in agricultural or nonturf situations, herbicide resistance genes should not be added to this species, unless other means of weed control is developed. Sterile hybrid bermudagrass cultivars with herbicide resistance might be developed; many triploid cultivars have been developed for turfgrass use, all of which are sterile.

If herbicide resistance is incorporated into Kentucky bluegrass, creeping bentgrass, or St . Augustinegrass and these are subsequently released to the market, they are not likely to become major agricultural weeds, or result in the transfer of the resistance to other species. However, because each characteristic, species, and management system is unique, evaluation of each transformed genotype will be needed.

\section{ECONOMICS}

Transforming, testing, and releasing an herbicide-resistant plant is a costly venture. Nevertheless, the turfgrass market is large enough to allow recovery of the costs. As mentioned previously, the turfgrass seed market is second in size, behind hybrid seed corn (Lee, 1996). Rapid urban growth around the country virtually ensures market growth for transgenic turfgrass seed, sod, and related chemicals. As a result, seed and sod producers are joining with biotechnology companies and university personnel in genetic transformation work.

Herbicide-resistant turfgrasses will be released on the market first because the genes are already available and have been used in other crops. But herbicides are also the pesticides most commonly used on turf. About 88 lawn-care firms in the Atlanta-metro area (only $25 \%$ of the total number of companies) applied $>93,000 \mathrm{~kg}$ a.i. of herbicide in 1993 , in addition to $13,000 \mathrm{~kg}$ a.i. of insecticide and $3800 \mathrm{~kg}$ a.i. of fungicide (Braman et al., 1997). Economics appear to support herbicide-resistant turfgrasses in the market.

Substantial growth and profit opportunities exist in turf production as well. Proprietary vegetative (sod) cultivars will be successful. As of 1997, the annual retail value of nearly 74,000 ha of sod produced in eight southern states was estimated at >U.S. $\$ 600$ million. When herbicide-resistant varieties and cultivars are available, a significant price premium can be charged. When these numbers are expanded to include both seed and sod over the entire United States, the economic impact and profit potential of turf production alone is large (Milberger/Crenshaw, Inc., 1997).

The most profitable marketing situations are proprietary annual-hybrids whose seed is purchased every year (Dyer et al., 1993). This type of market is not available in turfgrasses because of the perennial nature of the plants. An exception might be the winter overseeding market where golf courses and other highvalue turf are reseeded each winter to provide actively growing turf while the underlying bermudagrass is dormant.

Whether turfgrass managers will realize cost benefits is not known, since the costs of genetically engineered seed and sod will be higher. However, seed and sod are usually a small part of a manager's budget. Turfgrass quality will probably increase if these products and technology are used correctly.

The biotechnology industry is a very rapidly growing, changing, and financially volatile business. A very active area of academics and public policy is understanding the impacts of patents on plant and genetic material, protection of intellectual property rights, and licensing of techniques. The turfgrass arena is no exception. Numerous technology acquisitions have occurred and partnerships created. For example, the Scotts Company has exclusive license to use biolistic transformation technology in turfgrasses. Herbicide resistance genes are owned by Monsanto and AgrEvo. These technology acquisitions may not limit availability of the products to the end user, but may reduce the variety of genetic backgrounds into which the genes may be inserted. At present, other transformation techniques, such as electroporation and Agrobacterium-mediated transfer (recently developed for monocots), are available without restrictions.

\section{CONSUMER PERCEPTIONS}

The "science" of transforming turfgrass with herbicide resistance genes offers plenty of roadblocks to development, but none appear insurmountable. However, science and agriculture also must consider the perceptions of biotechnology products among potential consumers of the product. Unlike other industries, such as electronics, vehicles, medicine, etc., where new technology is largely looked upon as favorable, the public image of agricultural biotechnology is poor. A recent survey of New Jersey residents gives interesting insights into these perceptions and those of agriculture in general (Hallman, 1995). Although this was not a broad-based survey, it indicates how the public perceives these potential products. Biotechnology policies, like issues surrounding pesticides, will be shaped not by true risks, but by perceived ones (Higley et al., 1992).

According to the New Jersey survey (Hallman, 1995), 20\% of the public had a negative first reaction to "biotechnology," $4 \%$ responded positively, $25 \%$ had no opinion, and $25 \%$ were neutral. Obviously, those of us in biotechnology or agriculture have a view very different from that of the majority of Americans. Other results of the survey indicate a clear lack of knowledge, or information, of traditional plant breeding. Only $28 \%$ of respondents thought they had eaten a hybrid fruit or vegetable, $40 \%$ do not approve of traditional crossbreeding of plants, and $20 \%$ feel it is morally wrong. These negative responses are even higher for animal breeding. This New Jersey survey is not unusual; several other surveys have come to similar conclusions (Hallman, 1995). Biotechnology has religious overtones, with the perception of "playing God" (Lacy et al., 1991). On the other hand, the New Jersey survey indicated that most people are willing to buy products of biotechnology provided they have health or environmental benefits, or save time and money. People are more focused on the product than on the process, and are more accepting of technologies that are voluntary, controlled by individuals, familiar, and risky in known ways (Lacy et al., 1991). The majority believes that the benefits of technology will outweigh the risks. However, public support has shifted toward increased control of the development of technology (Lacy et al., 1991). How would the public perceive the products of turf biotechnology? We will not know until surveys have been made.

\section{SUMMARY AND CONCLUSIONS}

Turfgrass breeding has been, and will be more so in the future, affected by biotechnology, especially genetic transformation. Because of relatively little basic knowledge about turfgrass systems, we have little hard evidence to use when addressing questions as to the safety and proper use of transgenic turf. Herbicide-resistant varieties of turf offer many potential benefits and potential problems. Information from other areas of agriculture can help here.

Overall, turfgrass species offer relatively little danger of releasing harmful transgenes into the environment, or causing the plants to be problems themselves. There are a few exceptions. The biggest concern is resistance developing in weed populations, especially in a perennial crop where herbicides are applied year after year. With additional research and proper management, these risks can be minimized.

Many of the questions raised cannot be answered satisfactorily based upon existing data. Additional research on the ecological effects of the transgenes in turfgrass communities and larger-scale release with careful monitoring is needed to fully understand the ecological and safety concerns.

\section{Literature Cited}

Andow, D.A. 1994. Community response to transgenic plant release: Using mathematical theory to predict effects of transgenic plant. Mol. Ecol. 3:65-70.

Arias, D.M. and L.H. Rieseberg. 1994. Gene flow between cultivated and wild sunflowers. Theor. Appl. Genet. 89:655-660. 


\section{FEATURE}

Arnoldo, M., C.L. Baszczynski, G. Bellemare, G. Brown, J. Carlson, B. Gillespie, B. Huang, N. MacLean, W.D. MacRae, G. Rayner, S. Rozakis, M. Westecott, and R.J. Kemble. 1992. Evaluation of transgenic canola plants under field conditions. Genome 35:58-63.

Bazzaz,F.A. 1986. Life history of colonizing plants: Some demographic, genetic, and physiological features, p. 96-110. In: H.A. Mooney and J.A. Drake (eds.). Ecology of biological invasions of North America and Hawaii. vol. 58, Ecological studies ser. Springer-Verlag, New York.

Bergelson, J., C.B. Purrington, C.J. Palm, and J.C. Lopez-Gutierrez. 1996. Costs of resistance: A test using transgenic Arabidopsis thaliana. Proc. Royal Soc. London, Ser. B-Biol. Sci. 263:16591663.

Braman, S.K., R.D. Oetting, and W. Florkowski. 1997. Assessment of pesticide use by commercial landscape maintenance and lawn care firms in Georgia. J. Entomol. Sci. 32:403-411.

Crawley, M.J., R.S. Hails, M. Rees, D. Kohn, and J. Buxton. 1993. Ecology of transgenic oilseed rape in natural habitats. Nature 363:620-623.

Dale, P.J. 1993. The release of transgenic plants into agriculture. J. Agr. Sci. 120:1-5.

Dale, P.J. and J.A. Irwin. 1995. The release of transgenic plants from containment, and the move towards their widespread use in agriculture. Euphytica 85:425-431.

Daniell, H., R. Datta, S. Varma, S. Gray, and S.-B. Lee. 1998. Containment of herbicide resistance through genetic engineering of the chloroplast genome. Nature Biotech. 16:345-348.

Darmency, H. and J. Gasquez. 1983. Interpreting the evolution of a triazine-resistant population of Poa аппиа L. New Phytol. 95:299-304.

DeGreef, W., R. Delon, M. De Block, J. Leemans, and J. Botterman. 1989. Evaluation of herbicide resistance in transgenic crops under field conditions. Bio/Technol. 7:61-64.

Dyer, W.E., F.D. Hess, J.S. Hold, and S.O. Duke 1993. Potential benefits and risks of herbicideresistant crops produced by biotechnology. Hort. Rev. 15:367-408.

Fredshaven, J.R. and G.S. Poulsen. 1996. Growth behavior and competitive ability of transgenic crops. Field Crops Res. 45:11-18.

Gallie, D.R. 1998. Controlling gene expression in transgenics. Current Opinion Plant Biol. 1:166172.

Gatz, C. and I. Lenk. 1998. Promoters that respond to chemical inducers. Trends Plant Sci. 3:352-358.

Hallman, W.K. 1995. Public perceptions of agri-biotechnology. Genet. Eng. News 15(13) July 1995.

Hancock, J.F., R. Grumet, and S.C. Hokanson. 1996. The opportunity for escape of engineered genes from transgenic crops. HortScience 31:10801085. ton, D.C.
Heap, I.M. 1997. The occurrence of herbicide-resistant weeds worldwide. Pesticide Sci. 51:235243.

Higley, L.G., M.R. Zeiss, W.K. Wintersteen, and L.P. Pedigo. 1992. National pesticide policy: A call for action. Amer. Entomol. 38:139-146.

Hitchcock, A.S. 1950. Manual of grasses of the United States. U.S. Govt. Print. Off., Washing-

Holmberg, N. and L. Bulow. 1998. Improving stress tolerance in plants by gene transfer. Trends Plant Sci. 3(2):61-66.

Johnson, P.G. 1995. Genetics and physiology of flowering in selected Pоа аппиа L. genotypes. PhD Diss., Dept. of Horticulture, Univ. of Minnesota, St. Paul. (Diss. Abstr. ACC-9537872.)

Johnson, P.G., B.A Ruemmele, P. Velguth, D.B. White, and P.D. Ascher. 1993. An overview of the reproductive biology of Poа аппиа. Intl. Turfgrass Res. Soc. J. 7:798-804.

Jones, K. 1956a. Species differentiation in Agrostis. I. Cytological relationships in Agrostis canina L. J. Genet. 54:370-376.

Jones, K. 1956b. Species differentiation in Agrostis. II. The significance of chromosome pairing in the tetraploid hybrids of Agrostis canina subsp. Montana Hartm, A. tenuis Sibth. and A. stolonifera L. J. Genet. 54:377-393.

Jones, K. 1956c. Species differentiation in Agrostis. III. Agrostis gigantea Roth. and its hybrids with A. tenuis Sibth. and A. stolonifera L. J. Genet. 54:394-399.

Lacy, W.B., L. Busch, and L.R. Lacy. 1991. Public perceptions of agricultural biotechnology, $\mathrm{p}$. 67-79. In: B.R. Baumgardt and M.A. Martin (eds.). Agricultural biotechnology: Issues and choices. Purdue Univ. Agr. Expt. Sta., West Lafayette, Ind.

LeBaron, H.M. and J. McFarland. 1990. Herbicide resistance in weeds and crops, p. 336-352. In: M.B. Green, H.M. LeBaron, and W.K. Moberg (eds.). Managing resistance to agrochemicals: From fundamental research to practical strategies. Amer. Chem. Soc., Washington, D.C.

Lee, L. 1996. Turfgrass biotechnology. Plant Sci. 115:1-8.

Lee, L., C.L. Laramore, P.R. Day, and N.E. Turner. 1996. Transformation and regeneration of creeping bentgrass (Agrostis palustris Huds) protoplasts. Crop Sci. 36:401-406.

Liu, C.A., H. Zhong, J. Vargas, D. Penner, and M. Sticklen. 1998. Prevention of fungal diseases in transgenic bialaphos- and glufosinate-resistant creeping bentgrass (Agrostis palustris). Weed Sci. 46:139-146.

Luby, J.J. and R.J. McNicol. 1995. Gene flow from cultivated to wild raspberries in Scotland: Developing a basis for risk management for testing and deployment of transgenic cultivars. Theo.
Appl. Genet. 90:1133-1137.

Lush, W.M. 1988. Biology of Pоа аппиа in a temperate zone golf putting green (Agrostis stolonifera/Poa аппиа). II. The seed bank. J. Appl. Ecol. 25:989-997.

Marois, J.J., J.I. Grieshop, and L.J. Butler. 1991. Environmental risks and benefits of agricultural biotechnology, p. 136-161. In: B.R. Baumgardt and M.A. Martin (eds.). Agricultural biotechnology: Issues and choices. Purdue Univ. Agr. Exp. Sta., West Lafayette, Ind.

Milberger/Crenshaw Inc. 1997. Genetically tailored turfgrass marketing proposal. Prepared by Milberger/Crenshaw Turfgrass, Austin, Texas.

Moss, S.R. and B. Rubin. 1993. Herbicide resistant weeds: A world-wide perspective. J. Agr. Sci. 120:141-148

Pratley, J., P. Bains, P. Eberbach, M. Incerti, and J. Broster. 1996. Glyphosate resistance in annual ryegrass. Proc. 11th Annu. Conf. Grassland Soc. Wagga Wagga NSW, 10-11 July 1996.

Putwain, P.D. 1990. The resistance of plant to herbicides, p. 217-242. In: R.J. Hance and K. Holly (eds.). Weed control handbook principles. 8th ed. Blackwell Scientific, Oxford.

Rodgers, H.J. and H.C. Parkes. 1995. Transgenic plants and the environment. J. Expt. Bot. 46:467488 .

Saari, L.L., J.C Cotterman, and D.C. Thill. 1994. Resistance to Acetolactate synthase inhibiting herbicides, p. 83-139. In: Herbicide resistance in plants. CRC Press, Boca Raton, Fla.

Service, R.F. 1998. Seed-sterilizing 'Terminator Technology' sows discord. Science 282:850 851.

Spangenberg, G.,Z.Y. Wang, and I. Potrykus. 1998 Biotechnology in fescues and ryegrasses: Methods and perspectives, p. 223-228. In: M.B. Sticklen and M.P. Kenna (eds.). Turfgrass biotechnology: Cell and molecular genetic approaches to turfgrass improvement. Ann Arbor Press, Chelsea, Mich.

USDA-APHIS (U.S. Dept. of Agriculture and Animal and Plant Health Information Service). Obtained through the Information Systems for Biotechnology (http://www.nbiap.vt.edu), 3 Dec. 1998.

Warkentin, D., B. Chai, C.-A. Liu, R.K. Hajela, H. Zhong, and M.B. Sticklen. 1998. Development of transgeneic creeping bentgrass (Agrostis palustris Huds.) for fungal disease resistance, $\mathrm{p}$. 153-164. In: M.B. Sticklen and M.P. Kenna (eds.). Turfgrass biotechnology: Cell and molecular genetic approaches to turfgrass improvement. Ann Arbor Press, Chelsea, Mich.

Wu., L., I. Till-Bottraud, and A. Torres. 1987. Genetic differentiation in temperature-enforced seed dormancy among golf course populations of Poa annua L. New Phytol. 107:623-631. 